\title{
NEAR-TERM ELECTRIC VEHICLE PROGRAM PHASE II
}

\author{
TEST PLAN
}

INTEGRATED VEHICLE TESTS

WBS 4.6

Contract DE-AC03-79CS51294

28 April 1977 through 28 April 1979

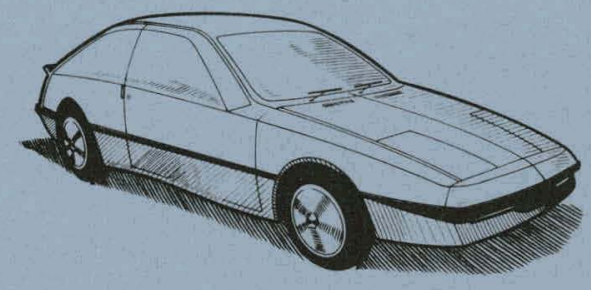

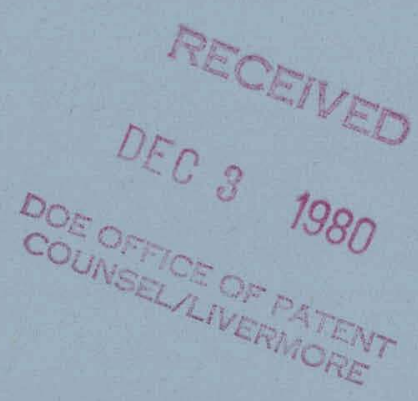

Submitted by

General Electric Company Corporate Research and Development Schenectady, New York

1 December 1978 


\section{DISCLAIMER}

This report was prepared as an account of work sponsored by an agency of the United States Government. Neither the United States Government nor any agency Thereof, nor any of their employees, makes any warranty, express or implied, or assumes any legal liability or responsibility for the accuracy, completeness, or usefulness of any information, apparatus, product, or process disclosed, or represents that its use would not infringe privately owned rights. Reference herein to any specific commercial product, process, or service by trade name, trademark, manufacturer, or otherwise does not necessarily constitute or imply its endorsement, recommendation, or favoring by the United States Government or any agency thereof. The views and opinions of authors expressed herein do not necessarily state or reflect those of the United States Government or any agency thereof. 


\section{DISCLAIMER}

Portions of this document may be illegible in electronic image products. Images are produced from the best available original document. 


\title{
NEAR-TERM ELECTRIC VEHICLE PROGRAM \\ PHASE II
}

\author{
TEST PLAN \\ INTEGRATED VEHICLE TESTS \\ WBS 4.6
}

REVISION 3, DECEMBER 1, 1978

ORGANIZATION

GE SYSTEMS ENGINEERING

GE PROGRAM MANAGER
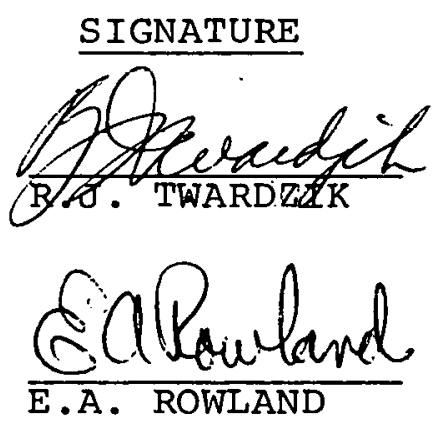

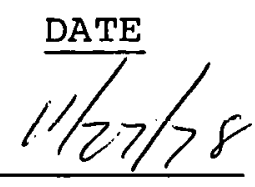

$11 / 27 / 78$

This book was prepared as an accounn of work sponsored by an agency of the United States Government. This book was prepared as an account of work sponsoned by an agency or the United States Government.
Neither the United States Government nor any agency thereot. not any of their employees. makes any warranty. express or implied, or assumes amy legal liability or responsibility tor the becouracy. completeness, or usefulness of any information. opparatus. product. of process disclosed, or represents that its use would not intringe privately owned righis, Reference herein to any specific commercial product, process, or service by trade name, trademark, manufacturer, or otherwise, does

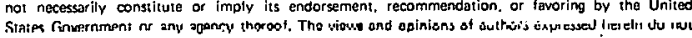
necessar ily state or reflect those of the United States Government or any ogency thereol. 


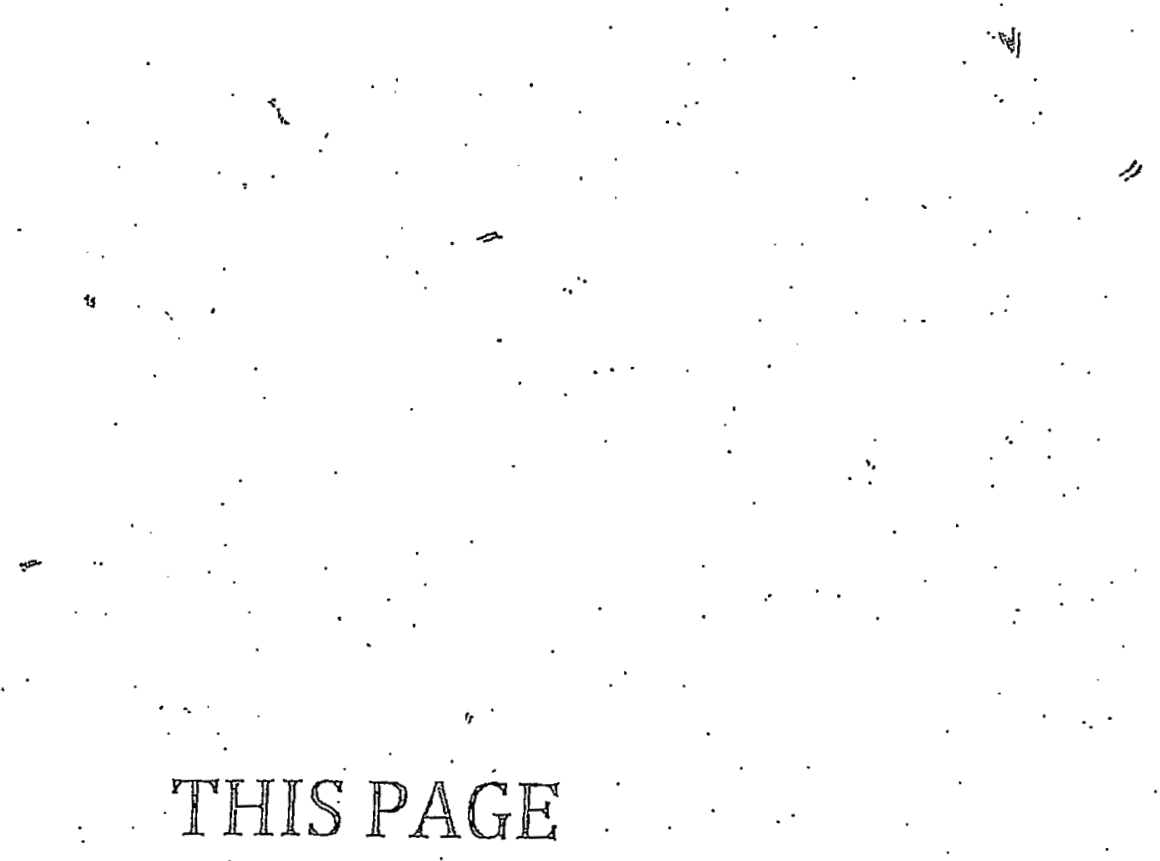

WAS INTENTIONALLY

LEET BLANK 
TABLE OF CONTENTS

Section

$\underline{\text { Page }}$

1.0 OBJECTIVE . . . . . . . . . . . . . . . . . . 1

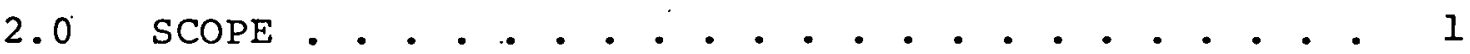

3.0 TERMINOLOGY . . . . . . . . . . . . . . . . . 1

3.1 Curb Weight. . . . . . . . . . . . . 1

3.2 Drive Line Ratio.............. 1

3.3 Građabll1ty. . . . . . . . ....... 2

3.4 Battery Initial State of Charge. . . . . . . 2

3.5 Projected Frontal Area . . . . . . . . . 2

3.6 Tractive Force . . . . . . . . . . . . 2

3.7 Tire Rolling Radius. . . . . . . . . . . 2

3.8 Maximum Cruise Speed . . . . . . . . . . 2

3.9 Gross Vehicle Weight . . . . . . . . . . 2

3.10 Vehicle Test Weight. . . . . . . . . . 2

4.0 VEHICLE/BATTERY CONDITION . . . . . . . . . . . 2

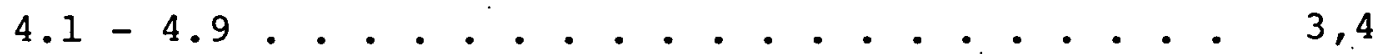

5.0 ENVIRONMENTAL CONDITION . . . . . . . . . . . . 4

6.0 INSTRUMENTATION . . . . . . . . . . . . . . . 5

6.1 General Instrumentation. . . . . . . . . 5

7.0 DATA TO BE RECORDED . . . . . . . . . . . . . 6

7.1 Manual Recording . . . . . . . . . 6

7.2 Chart Recording. . . . . . . . . . . . 7

7.3 Daily Checkout . . . . . . . . . . . 7

7. 1 Protect Checkout . . . . . . . . . . . . . 7

8.0 TESTS . . . . . . . . . . . . . . . 8

8.1 Range on SAE J227a Schedule D Driving Cycle

(Group 1). . . . . . . . . . . 8

8.1.1 Purpose of Test. . . . . . . . . . . 8

8.1.2 Definition of Test Cycle........ . 8

8.1.3 Road Test. . . . . . . . . . . . . 9

8.2 Range at Constant speed (Groups 1 and 2 ) . . 9

8.2.1 Purpose of Test. . . . . . . . . . . . 9

8.2.2 Definition of Test ................ . . . 9

8.2.3 Road Test. . . . . . . . . . . . 9

8.3 Maximum Level Speed (Group i). . . . . . 10

8.3.1 Purpose of Test. . . . . . . . . . . . . 10

8.3.2 Definition of Test... . . . . . . . 10

8.3.3 Road Test. . . . . . . . . . . . . 10 
TABLE OF CONTENTS (CONT'D)

$\underline{\text { Section }}$

$\underline{\text { Page }}$

8.0 TESTS (cont' $d$ )

8.4 Acceleration (Group 1). . . . . . . . . 10

8.4.1 Purpose of Test . . . . . . . . . . . . 10

8.4.2 Road Test................... 10

8.4.2.1 Acceleration from 0 to $60 \mathrm{mph}$ (or peak

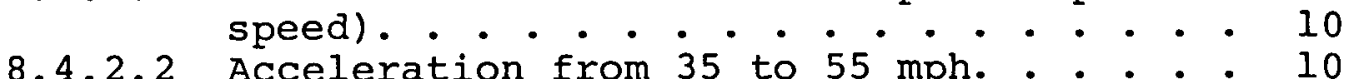

8.4.2.3 Special Data Recording. . . . . . . . 10

8.5 Sustained Speed on 58 Grade (Group 1) . . . . 11

8.5.1 Purpose of Test . . . . . . . . . . . . 11

8.5.2 Test Procedure. . . . . . . . . . . . 11

8.6 Gradability (Group 1) . . . . . . . . . . 11

8.6.1 Purpose of Test . . . . . . . . . . . 11

8.6.2 Test procedure. . . . . . . . . . . . . 11

8.6.3 Calculation of Gradability Limit. . . . . . 12

8.7 Recharge Capability (Groups 1 and 2). . . . 12

8.7.1 Purpose of Test... . . . . . . . . . 12

8.7.2 Battery Charger Capability. . . . . . . . 12

8.7.3 Recharge Energy .. . . . . . . . . . . 12

8.7.4 Energy Economy. . . . . . . . . . . . . 12

8.8 Environmental (Group 2) . . . . . . . . . . 13

8.8.1 Purpose of Test... . . . . . . . . . . 13

8.8.2 Splash and Water Test... . . . . . . . 13

8.8.3 Subjective Shake and Noise Level Evaluation 13

8.9 Subjective Ride, Handling and Braking

Evaluation (Groups 1 and 2) . . . . . . . 13

8.9.1 Purpose of Test.............. . 13

8.9.2 Test procedures.............. . 13

8.10 Subjective Electrical Noise Evaluation

(Grnur 1)................ 13

8.10.1 Purpose of Test. . . . . . . . . . . . 13

8.10.2 Test procedure . . . . . . . . . . . . 13

8.11 Mutual Noise Interference Checkout (Groups I

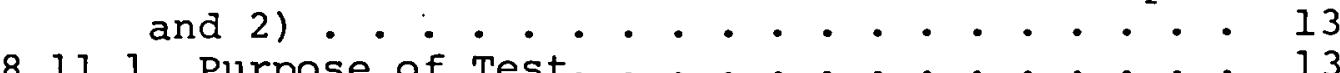

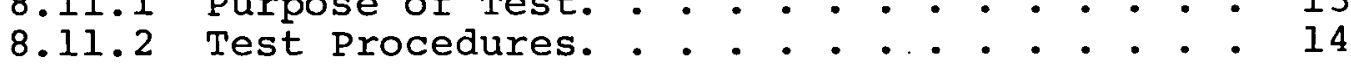

9.0 FACILITIES . . . . . . . . . . . . . . . 14

9.1 Oval Test Track............... . 14

9.2 Straightaways . . . . . . . . . . . . . 14

9.3 Ride and Development Road... . . . . . . 14

9.4 Dynamic Handling Facility . . . . . . . . . 15

19.5 Skid Test Facility. . . . . . . . . . . . . 15

9.6 Test Circle................. . 15

9.7 Water Troinghs.... . . . . . . . . . 15

9.8 Engineering Building. . . . . . . . . . . . 15 
TABLE OF CONTENTS (CONT'D)

Section

$\underline{\text { Page }}$

10.0 TEST SCHEDULE. . . . . . . . . . . . . . . 15

\section{LIST OF ILLUSTRATIONS}

\section{Figure}

l SAE J227a Schedule D . . . . . . . . . . . . 9

2 Simulation of a 5-Percent Grade. . . . . . . . . . 11

3 ITV Performance Tests. . . . . . . . . . . . 16

Table

1 . . . . . . . . . . . . . . . . . 8 


\subsection{OBJECTIVE}

The Integrated Vehicle Tests will be performed to determine the degree to which the Department of Energy (DOE) performance goals have been met, to provide a subjective evaluation of the regenerative brake system, to provide a subjective ride and handling evaluation, and to provide a general customer acceptability review. The specific tests covered in this plan are subdivided into two groups. Group I tests will be performed on the first available vehicle and will, in general, concentrate on performance tests to satisfy the DOE goals. Group 2 tests, to be performed on Vehicle \#2, will provide additional test data (braking, suspension system, shake, noise level, ride and handling evaluations, and general customer acceptability review).

\section{$2.0 \quad$ SCOPE}

The specific tests covered by this section are --

- Range on prescribed driving cycle (SAE J227a Schedule D)

- Range at constant speed

- Maximum speed on level road

- Acceleration on level road: 0 to $30 \mathrm{mph} ; 25$ to $55 \mathrm{mph}$

- Gradability: sustained speed on $1 \mathrm{mi}$, $5 \%$ grade; gradeclimbing ability

- Recharge capability

- subjective ride handling and braking evaluation

- Subjective electrical noise evaluation

- Subjective shake and noise level evaluation

- splash and water test

\subsection{TERMINOLOGY}

3.1 Curb Weight

The total weight of the vehicle including batteries, lubricants, and other expendable supplies, but excluding driver, passengers, and other payloads.

\subsection{Drive Line Ratio}

The drive motor shaft rpm divided by the rpm of the traction wheels of the vehicle. 


\subsection{Gradability}

The maximum percent grade which the vehicle can traverse for a specified time at a specified speed. The gradability limit is the grade upon which the vehicle can just move forward.

\subsection{Battery Initial state of Charge}

The amount of energy stored in the battery expressed as a percent of the capacity obtainable from a fully charged battery when discharged at a rate equivalent to the vehicle maximum cruise speed discharge rates.

\subsection{Projected Frontal Area}

The total frontal area obtained by projecting the vehicle image on a vertical plane normal to the forward direction of travel.

\subsection{Tractive Force}

The force available from the driving wheels at the driving wheel-ground interface.

\subsection{Tire Rolling Radius}

The effective radius of a tire when it is deformed by the weight of the vehicle ballasted to its rated gross vehicle weight (SAE J670C).

\section{8 Maximum Cruise Speed}

The highest vehicle speed sustainable for at least two laps of the test loop under specified environmental road test conditions, starting with a fully charged battery.

\subsection{Gross Vehicle weight}

The total weight of the vehicle including batteries, lubricants, expendable supplies, driver, passengers, and other designated payload.

\subsection{0 vehicle Test Welght}

The vehicle weight during testing including batteries, lubricants, expendable supplies, driver, passengers, and other designated payload in the vehicle during test.

\subsection{VEHICLE/BATTERY CONDITION}

Two Integrated Test Vehicles (ITVs) will be available for testing. Before the Integrated Vehicle Tests are begun, the 
vehicles will be examined for completeness and condition. The vehicles are to be driven by test personnel for familiarization with handling and performance characteristics.

4.1 The vehicles will be tested in their normal configuration with all normal appendages, mirrors, bumpers, hubcaps, etc. Vehicle testing will be at rated gross vehicle weight (curb weight plus $600 \mathrm{lb}$ ).

4.2 The front wheel alignment will be checked to ensure that it is set to specifications.

4.3 Tire pressures will be set to design pressure and, initially, new tires will be used.

4. 4 Normal recommended lubricants will be employed.

4.5 Vehicle checks preliminary to test.

4.5.1 Check the ability to fully charge and equalize battery cells.

4.5.2 Check tire pressure for possible air leaks.

4.5.3 Check all lights for proper function.

4.5.4 Check all brakes for drag, air in hydraulic lines, etc.

4.5.5 Check all safety equipment for proper function.

4.5.6 Obtain weight of the vehicle without driver and test equipment and with fifth wheel off the scale but down so it is not included as part of the curb weight.

4.5.7 Obtain weight of vehicle with the driver, all test equipment, and ballast weight* to meet the 600 lb payload requirement. The fifth wheel will be up so it is included as part of the test equipment weight.

4.5.8 Check calibration of the instrumentation package, $\operatorname{recorder}(\mathrm{s})$ and fifth wheel.

4.5.9 Check operation of the vehicle on a short sample road test simulating all probable test conditions. Check out all channels of instrumentation and recorder(s).

${ }^{*}$ GVW (test weight) may vary $\pm 2 \%$ from specifications. Distribution of test load will be such that actual weight distribution is also willin 28 or specification. 
4.5.10 The vehicle will be stored before tests at an ambient temperature for sufficient time to allow the power train and chassis to reach the temperature range of 5 to $32^{\circ} \mathrm{C}\left(40\right.$ to $\left.90^{\circ} \mathrm{F}\right)$. Battery electrolyte temperature must be below $90^{\circ} \mathrm{F}$ when the tests begin.

4.6 Batteries will be fully charged and equalized per manufacturer's recommendation prior to performing tests.

4.7 If batteries are new or have been subjected to extended storage, the batteries will be cycled according to the manufacturer's recommendation prior to starting tests.

4.8 For tests requiring an $\mathrm{X}$-percent discharged battery at the start, the required initial state of charge will be established as follows:

To achieve $\mathrm{X}$-percent discharge of a fully charged battery, the battery will be discharged for $X$ percent of the fully charged total watt-hours by driving the vehicle at recommended cruise speed or discharging the battery through a load at an equivalent constant power. Test series should be planned to minimize the necessity for frequent discharge to the $\mathrm{X}$-percent value. Tests conducted with the battery partially discharged at the start must be initiated no longer than 10 minutes after the desired initial state of discharge is reached.

4.9 Before running tests, the battery capacity and quality will be verified according to the manufacturer's recommendations.

\subsection{ENVIRONMENTAL CONDITIONS}

Ambient temperature during road testing will be in the range of 40 to $90^{\circ} \mathrm{F}$. Range performance tests performed at ambient temperature in this range, however, will have appropriate range correction factors applied as a function of ambient temperature, or the vehicle will be stored at an ambient temperature of $80^{\circ} \mathrm{F}$ for sufficient time to allow the batteries, power train, and chassis to stabilize at $80^{\circ} \mathrm{F}$.

Road tests are to be performed on a road which is level to within $\pm 1 \%$ and having a hard, dry surface. Tests will be run in opposite directions when they are performed on a road test route. The direction of travel need not be reversed when operating on a closed test track.

The recorded wind speed at the test site during the test should not exceed $16 \mathrm{~km} / \mathrm{h}$ (10 mph); gusts should not exceed $24 \mathrm{~km} / \mathrm{h}$ (15 mph). 


\subsection{INSTRUMENTATION}

A list of instruments required to perform the tests specified in this section is given. The overall error in recording or indicating instruments will be no worse than $\pm 2 \%$ of the maximum value of the variable to be measured. Instrument calibration will be performed and documented.

\subsection{General Instrumentation}

The following are the instrumentation requirements for the tests described in this section:

- AC Kilowatt-hour meter

- Tire pressure gauge

- Ambient temperature gauge

- Selected location thermocouples, reference junction, thermocouple transfer switch, and temperature measurement device ( $P C U$, motor, battery, battery compartment, underhood, etc.)

- Battery voltage gauge (displayed in driver's compartment)

- Battery current gauge (displayed in driver's compartment)

- Stopwatch

- Battery hydrometer

- Vehicle velocity (displayed in driver's compartment) Weston mph meter

- Wind velocity indicator and recorder

- Multichannel strip chart recording system

- Fifth wheel

- NASA-Lewis cycile limer

- Standard available receivers and transmitters for electrical noise evaluation

- Vehicle distance in miles (digital display in driver's compartment - DDl.1)

- Vehicle distance in feet (digital display in driver's compartment - DD2.1)

- Battery voltage gauge (to measure open circuit voltage to correlate to specific gravity of batteries)

- Sensors to measure battery current, armature current and field current 
7.0 DATA TO BE RECORDED

\subsection{Manual Recording}

The following will be recorded for the tests specified in this section:

- Vehicle identification

- Overall dimensions

- Curb weight and test weight

- Battery manufacturer, type, rating, state of charge

- Watt-hours and time consumed during charging

- Battery temperature at start and end of each test

- Motor type, rating, and serial number

- Serial numbers of electrical drive subsystem components

- Tire manufacturer, type, size, rolling radius, pressures and temperatures before. and after test

- Environmental temperature during tests, wind velocity and direction during tests, precipitation during test, and mean test site altitude relative to sea level

- Listing of all instrumentation used in the test (manufacturer, model number, serial number) and most recent calibration date

- Running surface conditions (material and texture)

- Description of test route (road class, road surface type and condition, and the lengths and grades of the test route)

- Date and the starting and ending times of test

- Driver log

- Test procedure deviation and reason for deviation

- Accessories operational during test and time each accessory was on during test

- Battery open circuit voltage (as required)

- Battery specific gravity (as required)

- Ride and roli rates, caster, camber, toe pattern

- Roll angle

- Dry parking effort 
7.2 Chart Recording

The following data will be recorded for each road test:

- Battery current vs. time

- Battery voltage vs. time

- Motor armature current vs. time

- Motor field current vs. time

- Motor armature voltage vs. time

- Vehicle velocity vs. time - Weston mph meter

- Selected microprocessor function(s) vs. time

- Distance (I pulse/mile) vs. time on event channel DD2. 1

\subsection{Daily Checkout}

- Ensure that all fluid levels are as specified

- Check all electrical power connections for physical tightness and evidence of running hot

- Inspect tires for damage and wear

- Totque all wheel lug nuts to specification

- Set tire pressures and record pressures and temperatures on data sheets

- Ensure that the fifth wheel tire pressure is set at the manufacturer's specified pressure

- Install strip chart paper; label with test number and channel identities

- Record driver and observer identities. Weigh the test vehicle and record weight

- Record wind direction, wind speed, humidity, and ambient temperature (at beginning of test, midway through the test period, and at the end of the test period).

- Stabilize the electronics before beginning tests

- Obtain pretest zeros and electrical step calibrations. Repeat at the completion of a series of tests or at the end of a test day.

\subsection{Pretest Checkout}

- Ensure that the proper, or sufficient amount of charge is in the batteries 
- Ensure that there is sufficient paper in recorder; ensure that test number and channels are properly labeled.

- Record run to be made, direction, and course on a data sheet.

- Other pertinent checks and facts about the test.

\subsection{TESTS}

Table 1 summarizes the Group 1 and Group 2 tests that will be conducted on the Integrated Test Vehicles.

\section{Table 1}

PERFORMANCE TESTS

J227a Schedule D

Constant speed

Maximum Level speed

Acceleration

Sustained Speed on 5\% Grade

Gradability

Environmental

Recharge Capability

Subjective Ride, Handling, Braking Fvaluation

Subjective Electrical Noise Evaluation

Mutual Noise Interference Checkout

\section{GROUP $1 \quad$ GROUP 2}

$\mathrm{X}$

$\mathrm{X} \quad \mathrm{x}$

$\mathrm{X}$

$\mathrm{X}$

$\mathrm{X}$

$\mathrm{X}$

$\mathrm{X} \quad \mathrm{X}$

$\mathrm{X} \quad \mathrm{X}$

$\mathrm{X}$

$\mathrm{x} \quad \mathrm{X}$

The sections that follow detail the tests to be performed.

\subsection{Range on SAE J227a Schedule D Driving Cycle (Group 1)*}

8.1.1 Purpose of Test. The purpose of this test is to determine the maximum distance traveled and the energy consumed by the vehicle when operated on a level surface in a repeated driving cycle.

8.1.2 Definition of Test Cycle. The SAE J227a Schedule D driving cycle is shown in Figure 1 . The time base has prescribed tolerances, but the vehicle speed is specified only at the end of the acceleration and during cruise. Schedule $D$ requires acceleration to $45 \mathrm{mph}$ and cruise speed at $45 \mathrm{mph}$.

*Range tests may be performed at a suitable dynamometer facility. 


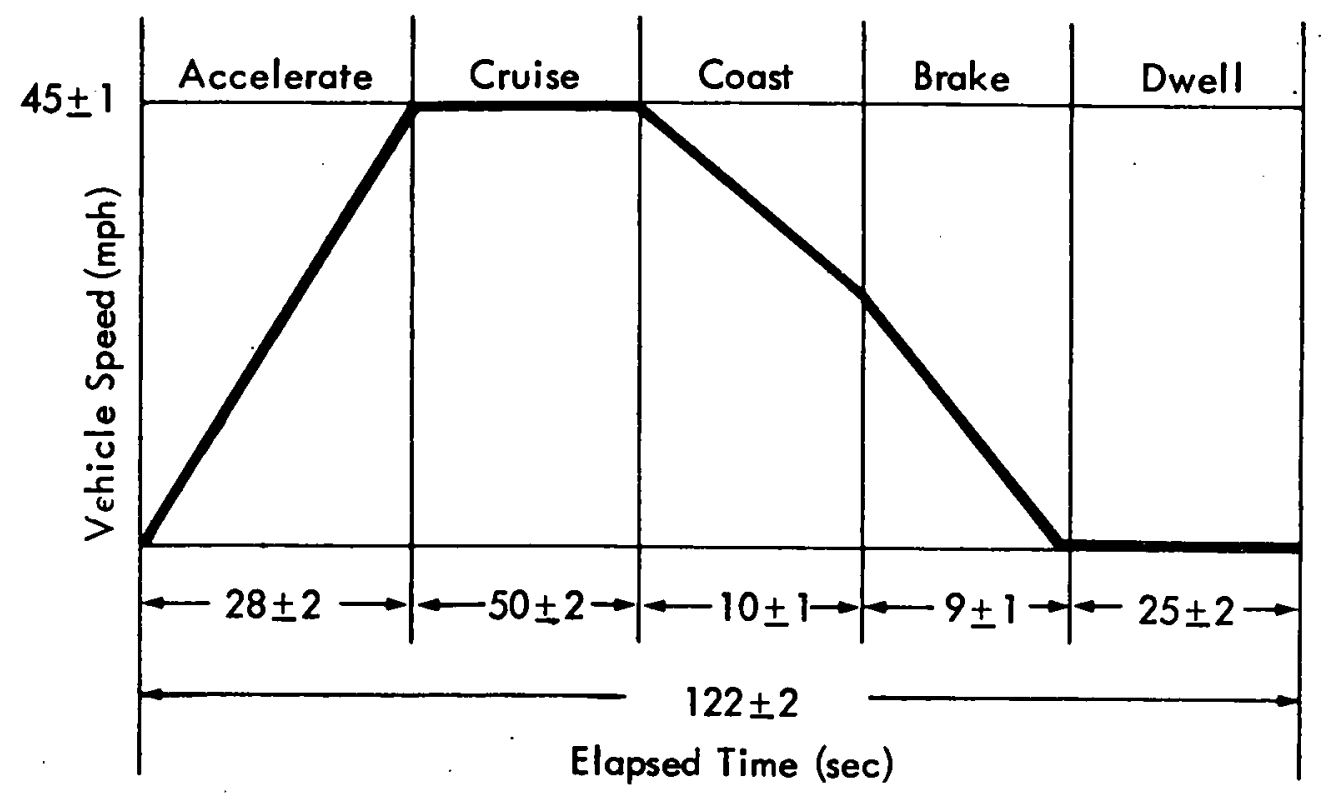

Figure 1. SAE J227a Schedule D

8.1.3 Road Test. The vehicle will be operated repeatedly starting with a fully charged battery and without interruption over the driving cycle on a level road or test track until it reaches the end of its range. The end of the driving range is defined as the end of the driving cycle immediately preceding the cycle in which the vehicle ceases to meet the requirements of the driving cycle or reaches some other vehicle performance limitation. The range will be determined as the average of at least two tests. Tests performed over a road test route will be run in opposite directions.

\subsection{Range at Constant Speed (Groups 1 and 2)*}

8.2.1 Purpose of Test. The purpose of this test is to determine the maximum distance traveled and the energy consumed by the vehicle when operating at various constant speeds.

8.2.2 Definition of Test. The vehicle will be accelerated at near constant $\mathrm{I}_{\mathrm{BAT}}$ until it achieves the constant speed called for.

8.2.3 Road Test. Steady state operation will include a minimum of two tests, starting with a fully charged battery and consisting

*Range tests may be performed at a suitable dynamometer facility. 
of operation at a prescribed constant speed maintained to within 5용 until the prescribed speed falls below $95 \%$ of the initially programmed steady speed. The prescribed constant speeds for this test will be $35 \mathrm{mph}$ and $55 \mathrm{mph}$. The range will be determined as the average of the two tests performed on an oval track or two tests in opposite directions performed on a road test route.

\subsection{Maximum Level Speed (Group 1)}

8.3.1 Purpose of Test. The purpose of this test is to determine the maximum speed which the vehicle can attain on a level road.

8.3.2 Definition of Test. The vehicle will be accelerated at near constant $\mathrm{I}_{\mathrm{BAT}}$ until it achieves a maximum speed, starting with a fully charged battery.

8.3.3 Road Test. The vehicle will be accelerated until it reaches a maximum speed. The vehicle will be operated at maximum speed for one minute while the speed is recorded. The test will be conducted once in each direction. This test will be performed at battery discharge levels of 0 and $60 \%$.*

\subsection{Acceleration (Group 1)}

8.4.I Purpose of Test. The purpose of this test is to determine the maximum acceleration that the vehicle can achieve on a level road as a measure of its ability to move in traffic.

8.4.2 Road Test. The tests may be run on a straight or oval test track. Testing performed on an oval track will be limited to one direction; testing performed on a straight track will be in two directions.

8.4.2.1 Acceleration from 0 to $60 \mathrm{mph}$ (or peak speed). The vehicle will be started from rest and subject to maximum acceleration until a speed of $60 \mathrm{mph}$ or peak speed is attained. This test will be performed at battery discharge levels of 0 and $60 \%$.*

8.4.2.2 Acceleration from $25 \mathrm{mph}$ to $55 \mathrm{mph}$. The vehicle will be operated at a steady speed of $25 \mathrm{mph}$ for a minimum of $5 \mathrm{~s}$. It will then be subjected to a maximum acceleration from $25 \mathrm{mph}$ to $55 \mathrm{mph}$. This test will be performed at battery discharge levels of 0 and $60 \% . *$ Testing on a straight track will be in two directions.

8.4.2.3 Special Data Recording. In addition to the data specified in section 7.0, the vehicle's acceleration characteristics will be tabulated and also plotted as speed vs. time.

*Tests conducted with the batteries partially discharged at the start must be initiated no longer than $10 \mathrm{~min}$ after the desired initial state of charge reached. 


\subsection{Sustained Speed on 5\% Grade (Group 1)}

8.5.1 Purpose of Test. The purpose of this test is to determine the maximum vehicle speed which the vehicle can maintain on a $5 \%$ grade.

8.5.2 Test Procedure. The 5응 grade will be simulated by towing an absorption vehicle on the oval test track. The ITV will be operated on the oval test track with the absorption vehicle in tow until a speed of $50 \mathrm{mph}$ is attained. The load due to the absorption vehicle will then be adjusted to simulate a 5\% grade. The ITV will then sustain this speed for 1 min for the simulated 5\% grade. A sketch indicating the relation of the test vehicle and the absorption vehicle is shown in Figure 2. This test will be performed at battery discharge levels of 0 and $60 \%$.

\subsection{Gradability (Group 1)}

8.6.1 Purpose of Test. The purpose of this test is to determine the maximum grade on which the vehicle can just move forward.

8.6.2 Test Procedure. Direct measurement of the gradability limit on steep test slopes is impractical. Therefore, the gradability limit is to be calculated from the gross vehicle test

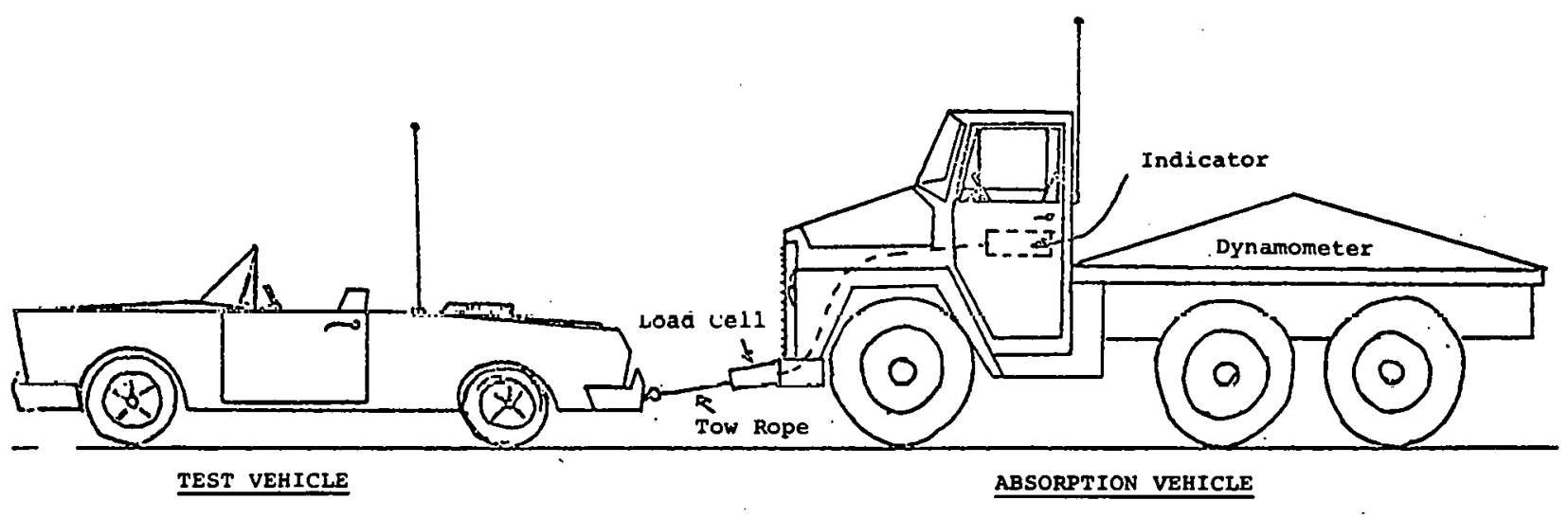

NOTE :

1. Load cell and indicator unit may be mounted on same vehicle (Either test vehicle or absorption vehicle.)

2. Tow rope must be horizontal within one foot vertical error per twenty feet vehicle separation.

3. Mount load cell so. it will not drag on pavement with slack tow rope.

Figure 2. Simulation of a 5-Percent Grade 
weight and the measured tractive force delivered by the vehicle at a speed near zero. The tractive force, defined as the maximum force which can be maintained by the vehicle propulsion system for a period of $20 \mathrm{~s}$ while moving the vehicle at $2 \mathrm{mph}$ will be measured on a horizontal surface. The battery will be in a fully charged state at the beginning of this test. Armature current will be limited to $400 \mathrm{~A}$. This test will be repeated for a battery discharge level of $60 \%$. If the traction force is limited by slippage between the vehicle drive wheels and the road, this fact will be recorded.

8.6.3 Calculation of Gradability Limit. The percent gradability limit will be determined by using the following relationship:

$$
\begin{gathered}
\text { Percent Gradability Limit }=100 \text { tan }\left(\sin ^{-1} \mathrm{P} / \mathrm{W}\right) \\
\text { where } \mathrm{P}=\text { measured traction force, } \\
\mathrm{W}=\text { gross vehicle weight, } 1 \mathrm{~b}
\end{gathered}
$$

\subsection{Recharge Capability (Groups 1 and 2)}

8.7.1 Purpose of Test. The purpose of this test is to determine the recharge capability of the onboard battery charger with both $15 \mathrm{~A}$ and $30 \mathrm{~A}$ circuits, and to determine the energy needed to recharge the battery.

8.7.2 Battery Charger Capability. The battery will be in an 80 \% discharged state at the start of the test. The onboard battery charger will be connected to a suitable 115 VAC power source (15A circuit). Battery charging will begin and will continue until the battery is fully charged. The time interval required will be recorded. The test will be repeated with the $30 \mathrm{~A}$ circuit.

8.7.3 Recharge Energy. The battery will be in an $80 \%$ discharged state at the start of the test. The battery charger will be connected to a suitable power source. Battery charging will begin and will continuc until the battery ie fully charged. The ar. energy delivered to the vehicle will be recorded. This test may be run concurrently with that of Paragraph 8.7.2, with the 115 VAC, 30A circuit.

8.7.4 Energy Economy. Vehicle energy economy is defined as the vehicle range for a particular operating mode, divided into the ac energy required to return the battery to its original state of charge. Energy economy is, therefore, a calculated value based on test data. The vehicle energy economy, therefore, is defined as follows:

Vehicle Energy Economy, $\mathrm{kWh} / \mathrm{mile}=\frac{\mathrm{AC} \text { Energy to Recharge Battery }}{\text { Range in Prescribed Driving Mode }}$

Vehicle energy economy values will be established for the J227a Schedule $D$ and constant speed driving modes specified in section 8.2 . 


\subsection{Environmental (Group 2)}

8.8.1 Purpose of Test. The purpose of the environmental tests is to record the results of the operation of the ITV under certain environmental conditions.

8.8.2 Splash and water Test. The ITV will be driven through a water trough having a 2 in. water depth. The speed of the vehicle for the initial run through the water will be $5 \mathrm{mph}$. For subsequent runs the speed of the vehicle will be increased in $5 \mathrm{mph}$ increments until a run speed of $30 \mathrm{mph}$ is achieved. At the end of each run, visual observation will be made and recorded.

8.8.3 Subjective Shake and Noise Level Evaluation. The ITV will be driven over various road surfaces, and a subjective shake and noise level evaluation will be made.

8.9 Subjective Ride, Handling and Braking Evaluation (Groups 1 and 2)

8.9.1 Purpose of Test. The purpose of the ride, handling and braking test is to evaluate the ride, handling and braking performance of the ITV.

8.9.2 Test procedures. A subjective evaluation of the ride, handling and braking performance during the road tests will be made. In addition, stopping distances from various speeds up to the maximum cruising speed will be measured and recorded.

\subsection{Subjective Electrical Noise Evaluation (Group 1)}

8.10.1 Purpose of Test. The purpose of these tests is to provide a subjective evaluation of operation of the ITV under realistic conditions of environmental noise, such as eminating from $C B$ transmitters, "ham" radio transmitters, FM/TV transmitters, and other available rf sources. In addition, a subjective evaluation of the ITV as a source of electrical noise will be made.

8.10.2 Test Procedure. Available receivers, $A M, F M, C B, V H F$, and a wide frequency coverage radio noise meter, will be operated in or in close proximity to the vehicle while the vehicle is under conditions of minimum speed, acceleration, constant speed, and maximum speed. Available sources of rf energy, such as CB, "ham" radio, and track security will be operated in close proximity to the vehicle during conditions of minimum speed, acceleration, constant speed and maximum speed. The vehicle will be driven in close proximity to an available nearby FM/TV station. Anomalies observed during these tests will be recorded.

8.11 Mutual Noise Interference Checkout (Groups 1 and 2)

8.11.1 Purpose of Test. The purpose of this test is to provide a subjective evaluation of mutual interference between two ITV's. 
8.11.2 Test procedure. When vehicle \#2 is available, mutual interference between vehicle \#1 and \#2 while in close proximity will be checked out under conditions of minimum speed, acceleration, constant speed, and maximum speed. Anomalies observed will be recorded.

\subsection{FACILITIES}

The extensive test and development program carried on at the Chelsea Proving Grounds requires the availability of many varied test facilities. Paved and unpaved roads, straightaways, curves of various radii, smooth and bumpy roads, and special-purpose facilities are designed and maintained by the Proving Grounds personnel for constant use by test engineers. The following sections describe the facilities.

\subsection{Oval Test Track}

The oval test track is used for high-speed durability, simulated city traffic, endurance cycling of engines, transmissions and rear axles, fuel economy measurements, brake performance, temperature measurements, and draw bar pull tests.

The track is a six-lane, concrete road 4.71 miles long. The width varies from $60 \mathrm{ft}$ in two $3757 \mathrm{ft}$ straightaways to $64 \mathrm{ft}$ in the $1800 \mathrm{ft}$ radius curves. The curves are designed to accommodate vehicle speed from 30 to $140 \mathrm{mph}$ without side thrust.

\subsection{Straightaways}

The two straightaways are used for stopping distance, acceleration, engine driveability, directional stability and force required tests.

The two concrete straightaways are located at right angles to each other to permit selection of the road to nullify the effects of wind. Both are straight, level, two-lane roads, 24 ft in width. The east-west road is $1.59 \mathrm{mi}$ long; the north-south road is $2.23 \mathrm{mi}$ long.

\subsection{Ride and Development Road}

This road is used to evaluate vehicles for ride, steering, body shake, noise, and vibration.

The road is 4-1/3 miles long, two and three lanes wide. One lane is a smooth sheet-asphalt surface for vehicle-induced noises and vibrations. The second lane incorporates various waveforms and rough surfaces. A shorter third lane is surfaced with crushed stone to initiate road noise. 


\subsection{Dynamic Handling Facility}

The dynamic handling facility is used for evaluating the steering, suspension, and braking characteristics of a vehicle during severe maneuvers at varying speeds up to $100 \mathrm{mph}$.

The basic feature is a $800 \mathrm{ft}$ square asphalt pad with 75 skid number surface, enclosed by a one lane oval road. The oval road permits the test vehicle to approach the pad from either the right or left side, perform a particular maneuver, recover and decay speed on the loop at the far end of the pad. The oval road is $2.7 \mathrm{mi}$ long, $16 \mathrm{ft}$ wide, and the curves are designed for $40 \mathrm{mph}$ speed.

\subsection{Skid Test Facility}

The skid test facility is used to determine vehicle stability and stopping distances on road surfaces with various degrees of slipperiness.

It consists of three parallel skid test lanes, a hydroplaning trough, a recover apron, and an approach road. The test lanes are concrete; each is $30 \mathrm{ft}$ wide and $100 \mathrm{ft}$ long. Two have wet skid numbers of 10 and 30 , respectively; the third has a dry skid number of 75. The hydroplaning trough is $1-1 / 2$ inches deep by 20 inches wide by $1000 \mathrm{ft}$ long. The test lanes are bordered.by $30 \mathrm{ft}-w i d e$ paved brims; a $160 \mathrm{ft}$ wide by $600 \mathrm{ft}$ long recovery apron is located at one end of the skid lanes. The entire length of the facility, including approach road, is $7500 \mathrm{ft}$.

\subsection{Test Circle}

The test circle is used to measure body roll angles for various angular accelerations. The facility is a flat, asphalt, $12 \mathrm{ft}-\mathrm{wide}$ road in the shape of a perfect circle, $1400 \mathrm{ft}$ in diameter.

\subsection{Water Troughs}

There are two water troughs, each of which will accommodate an entire vehicle. One is used to soak brakes prior to running a wet brake recovery test; the other is used to observe splash patterns and to develop splash shields for the engine compartment.

The brake soak trough can be filled to a depth of 24 in. for a length of $100 \mathrm{ft}$. The splash trough can handle depths from 1 to 8 inches for a total length of $600 \mathrm{ft}$.

\subsection{Engineering Building}

The largest building at the Chelsea Proving Ground houses passenger car and truck garages, laboratories, services, and offices. The total building area is $194,000 \mathrm{sq} f t$. 
The garage, containing $105,000 \mathrm{sq} \mathrm{ft}$, provides service stalls for 150 vehicles and includes such facilities as vehicle washrooms, lubrication racks, front-wheel alignment machines, platform scales for individual wheel loads, and tool-rooms. The garage also includes a truck buildup room for prototype models of future trucks.

The laboratory facilities include:

- Emissions certification laboratory with eight chassis dynamometers, infrared emissions measurement instruments with computerized data analysis and a temperaturecontrolled garage area to soak 40 vehicles.

- Carburetor laboratory with three flow stands to measure carburetor fuel and air flow rates accurately.

- Ride-roll rig to measure spring heights and body roll characteristics.

- Surface plate and instruments to determine accurately the measurements of a vehicle.

- Brake laboratory to build up experimental brake systems and to analyze brake components.

- Instrument laboratory to build and maintain specialized test instrumentation.

- Photographic laboratory to process film.

- Computer laboratory with an IBM 1130 computer and access to a CDC 6400 computer.

The Engineering Building also contains a shipping and receiving area, stock rooms, a conference room, and multipurpose room and food service facilities. The office portion of the building accommodates 210 people.

\subsection{TEST SCHEDULE}

Figure 3 delineates the test schedule and is shown for planning purposes only. The scheduling of specific tests during the allocated test period will be dependent on weather and facility availability. 
$\underline{I T V \# I}$

- Subjective Fide, Handling and Braking Evaluation

- J227a Schedule D

- Constant $55 \mathrm{mph}$

- Acceleratior (0-30 and 25-55 mph)

- Maximum Level speed

- $5 \%$ Grade; Gradability

- Subjective Electrical Noise Evaluation

- Recharge Capability; Energy Consumption

- Mutual Noise Interference Checkout

ITV \#2

- Subjective Ride, Handling and Braking Evaluation

- Shake, Noise Level, Splash and Water Test

- Constant $35 \mathrm{mph}$

- Mutual Noise Interference Checkout

- Recharge Capability; Energy Consumption

Figure 3. ITV Performance Tests 